\title{
New Zealand's Contribution to the British Diet
}

By C. S. M. Hopkirk (Veterinary Adviser to the New Zealand High Commissioner), New Zealand House, 415 Strand, London, W.C. 2

\section{Present position}

'To state the position of New Zealand food exports in concentrated form, I present Table I, which I believe to be reasonably accurate, showing quantities of food commodities received in Great Britain from New Zealand before the war, and for each year following 1938. Annual fluctuations will be noticed. Tables 2 and 3 give interesting data relating to production in New Zealand and to the effect of that production on the British market.

Dairy products. The immediate prewar average for butter was higher than normal because of a very good season for 1937, and it is not until 1948 and 1949 that we can show similar export figures. The change from butter to cheese production in 194r was due to Britain's decision to import only sufficient butter for a 2 oz. ration, but owing to a shortage of animal proteins to ask for maximum cheese supplies. In 1942 ample supplies of cheese became available from the U.S.A. on lease-lend, and the much shorter haul meant a substantial saving in tonnage; New Zealand was asked, therefore, to change her factories back to butter, and because Australian butter imports were falling rapidly at that time and demands for troops in the Pacific became substantial, the total available for shipment to Britain was only sufficient to maintain the $2 \mathrm{oz}$. ration which, in fact, ran from 30 June 194 I to I I November 1945 , when it was raised to $3 \mathrm{oz}$. The diversion of supplies of dairy products to overseas forces is plainly seen in the 1944-6 figures for preserved milk. In 1947, because of the needs of the mother country, butterfat production increased, and with excellent and lengthy dairying seasons heavy tonnage has resulted.

Increase in dairy products available for export has been secured for several reasons:

(I) With the return of farmers' sons from overseas more labour became available. Perhaps labour is the most critical factor in defining the quantity of dairy produce that can be produced and exported. Not only is farm labour chronically short, but so also is dairy factory labour-this in spite of good wages and a short working week of $44 \mathrm{hr}$., with overtime rates paid in the heavy part of the season. As in other countries, factory wages and conditions tempt young men and women from the land, and a Public Works Department which always has projects in hand is an added attraction. New Zealand is not a heavy industrial country, but several small industries have been set up and these act detrimentally to farming. At present, a farm labourer's gross wages are $£ 6$. $6 s .6 d$. for a $44 \mathrm{hr}$. week, which includes necessary week-end labour, and in the stabilization of prices brought about by guaranteed prices, labour costs are taken into consideration. For example, a farmer milking with one assistant forty-eight cows with a low average return of $215 \mathrm{lb}$. butterfat per cow receives a labour reward for himself of $f^{6} \mathrm{ro}$ per annum and for farm working and maintenance, including assistant's wages, $f_{43} \mathrm{I}$ per annum and a total income from the farm of filin4. 


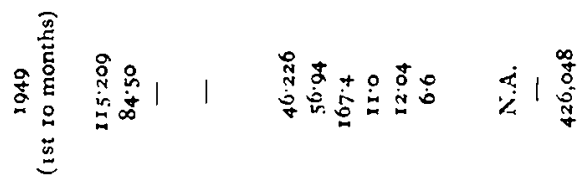

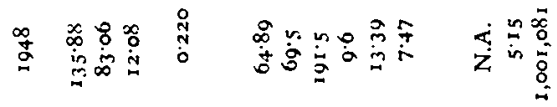

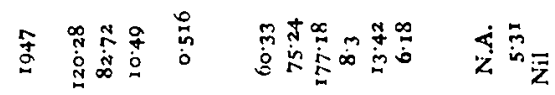

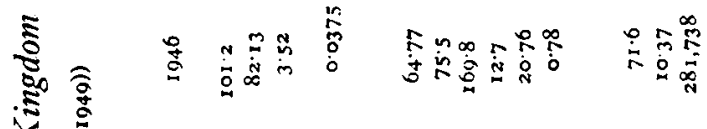

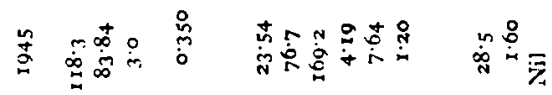

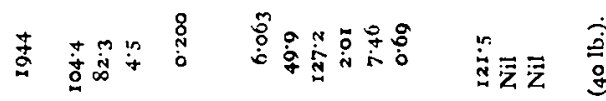

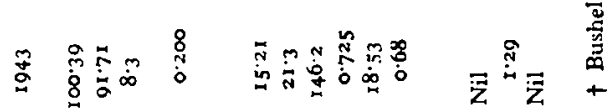

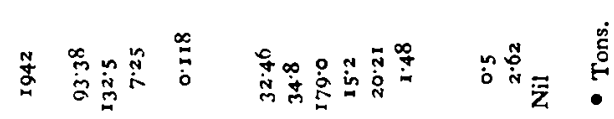

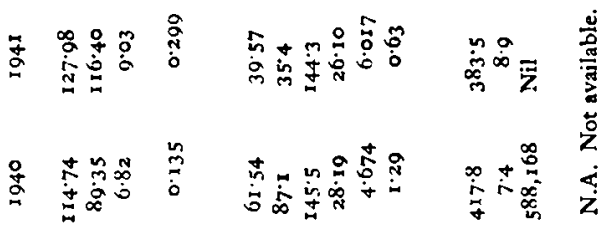

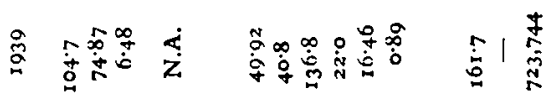

$\therefore$ 施

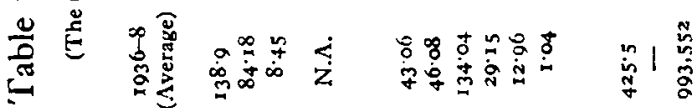

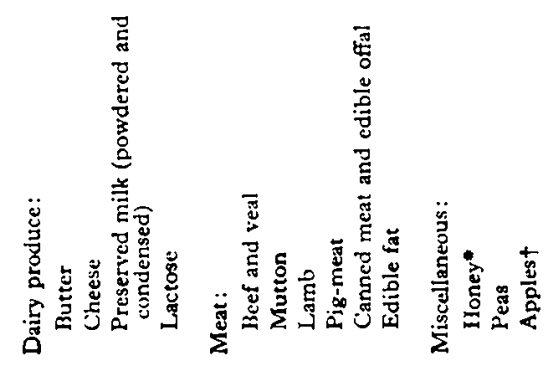


(2) Under New Zealand farming conditions, the pasture is grown as a permanent crop, and this requires feeding with superphosphate and lime to keep up high fertility of the soil. The whole of New Zealand's livestock farming depends almost solely on pasture, and all protein, fat and carbohydrates sent to Britain are evolved from pasture.

During the war, Nauru Island installations were destroyed, with the result that phosphate rationing had to be carried out. More phosphate is now available, and is reflected in increased dairy produce.

(3) Herd testing has increased and there has been a definite increase in the national herd average for butterfat to $245 \mathrm{lb}$./cow at pail. Some 400,000 cows are now under test and the latest figures of this group show an average of $279 \mathrm{lb}$./cow, with $305 \mathrm{lb}$./cow in the dairying district of Taranaki.

(4) Butter and cheese rationing has continued in New Zealand. Prewar butter consumption was about $42 \mathrm{lb}$. per head of population, whereas it dropped to $3 \mathrm{I} \mathrm{lb}$. during the war, and rose recently to $32 \cdot 5$. It should be realized that margarine is not used in New Zealand, but that there was access during the war to other animal fats to eke out the family needs.

(5) The guaranteed prices in 1949 of $252 \mathrm{~s}$. $6 \mathrm{~d}$./ cwt. butter and $14 \mathrm{Is}$. $6 \mathrm{~d}$. $/ \mathrm{cwt}$. cheese are considered by the farmer to be fair and equitable, and with a 7 -year agreement, with the proviso that $97 \%$ of exportable surplus must go to Great Britain for 1949-50 and thereafter by arrangement, and with a further proviso that prices cannot fluctuate more than a definite amount as decided annually by both parties, the dairy farmer is likely to continue optimum production and to increase it as promised.

(6) More use is now being made of waste skim milk and whey in producing byproducts, such as dried milk, lactose and casein.

Meat. It will at once be noted that there is no reference to poultry in Table I, and that pig-meat is not a major production. This is understandable when it is realized that New Zealand does not produce nearly sufficient grain for human consumption, let alone for stock feeding. Numbers of breeding sows are slowly dropping, and it is unlikely that New Zealand will be a serious producer in the pig-meat market.

rable I shows, too, that as with dairy products, meat, with the exception of lamb, was diverted for army use during 1943-5. As American troops did not appreciate lamb, there was little fall in exports to Britain of this commodity. Fluctuation in supplies results from the annual seasonal quality of pasture. It will be noted that, generally speaking, export of meat has been considerably increased over the past decade.

Other commodities. Production of peas and apples fluctuates for two reasons, one the New Zealand season and the other the requirements of the British market.

\section{Future production}

New Zealand has concluded a 7 -year agreement with Britain, 5 years of which have still to run. She is aiming at a minimum target of an annual increase of $2 \%$ of dairy products and an increase of 50,000 tons of meat by the end of the 7 -year period. That should be satisfactory, but good or bad seasons may alter the result considerably. A drought in the store-stock areas could easily prejudice the 50,000 ton increase in 
meat and cause a decrease in exports for the following 4 years. This 1949 season is, up to date, the best year known for dairy produce.

The increase of products will be brought about as follows:

(I) Fertilizer supplies are being increased, as it must be realized that superphosphate is the key to all high production in New Zealand. Further Government subsidies are suggested on lime and phosphate, with a reduction in rail charges. A new co-operative superphosphate works is to be built to serve the store-stock area of the east coast of the North Island. One of the enormous difficulties in hill country was the distribution of superphosphate. This is now being solved by aeroplane dispersal, and four aircraft of 9-ton capacity are being obtained for fertilizing hill country. Where copper and cobalt are deficient, they are added to the superphosphate, and assist in simultaneously controlling parasites and improving the health and growth of the young animal.

(2) Better strains of grass and clover are being introduced.

(3) Improvement in dairy supplies is being obtained by continuous increase in herd testing, sire surveys, artificial insemination with high-class bulls to improve herd average, and by better farming methods as shown by research work in the Agriculture Department and in agricultural colleges.

(4) In meat supplies, increase in beef production will be the main effort, but this will inevitably lead to increase in mutton and lamb as pastures improve. Fortunately, the British market has not yet reached the absorbable saturation point and can use the increase in small joints which New Zealand sends and will send. This applies also to beef, provided it is produced from the breeds with high meat:low bone ratio. Quality rather than quantity is still considered to be a necessity in our lamb trade, since at a future date it may be necessary to return to competitive practices, and the good name of New Zealand products would be essential. In fact, all meat has been held at high standard throughout the period under review. It is the aim of the governing bodies, the Weat Board and the Dairy Commission, that this quality should be maintained at all costs even with rise of production. Pork and bacon from New Zealand can never compete with those from grain-growing countries, where large quantities can be quickly produced, and this fact makes it uneconomical for the New Zealand farmer to spend more money on farm labour to grow pig-meat. There is likely to be a decline rather than an increase in this commodity. Were pig-meat a necessity from New Zealand, then the farmer could supply pork of an excellent grade fed on milk byproducts, meat meal and pasture as has been done in the past.

The increase since 1938 of $89.2 \%$ in the price received for pig-meat, and $82 \cdot 7 \%$ in that for meat and offal has been, and will continue to be, an incentive to produce good class meat. The buffer of $7: 2 \%$ increase or decrease in prices in any one year as decided by both parties to the agreement gives the farmer a feeling of security-a very necessary factor in increased production-and there are also accumulated funds in the hands of the Government and Meat Board which will further buffer downward trends.

(5) Control of disease, particularly mastitis and contagious abortion, must be having a marked effect on the future of production. Contagious abortion has been reduced in $50 \%$ of dairy herds to a level of $3 \%$, and penicillin treatment is keeping many cows at least one more year in production. 
Vol. 4

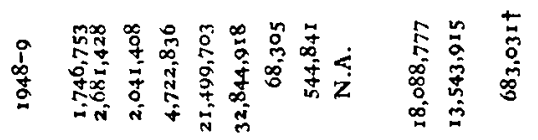

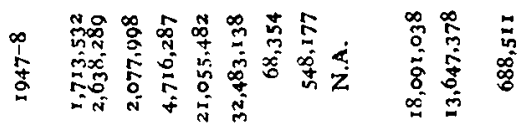

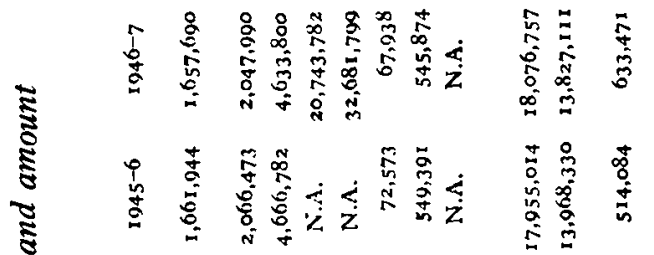

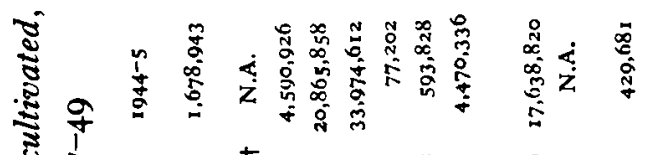

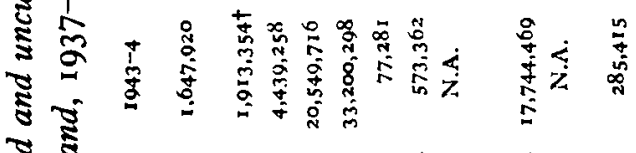

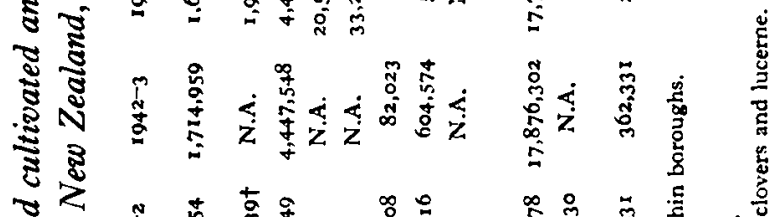

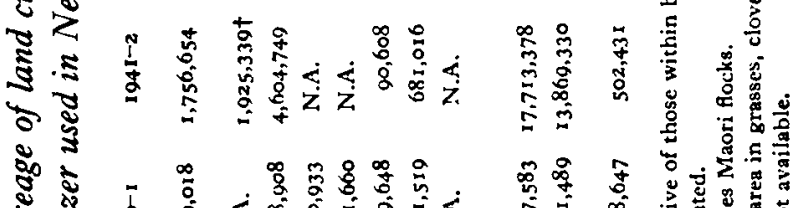

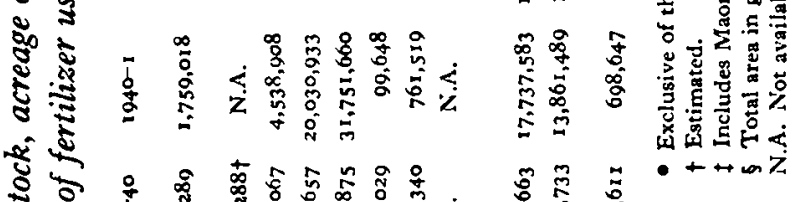

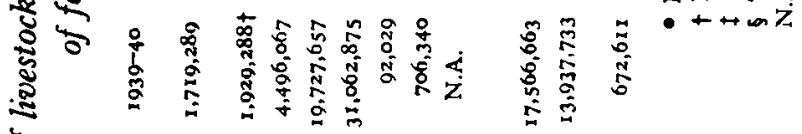

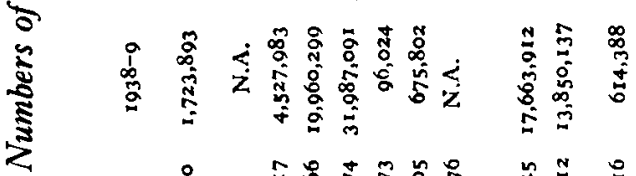

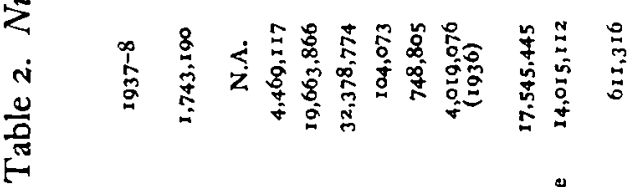

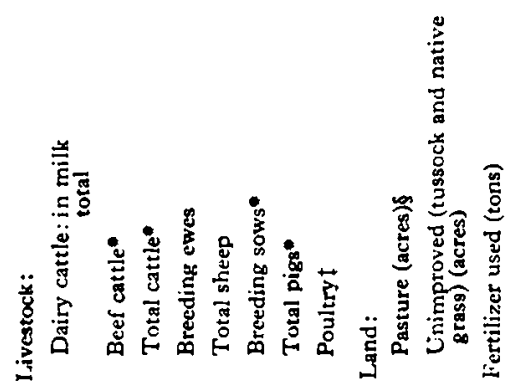


(6) Improvement of beef breeds and their crosses is being carried out. The whole structure of New Zealand farming is built on control of grazing by cattle, and the greater the use made of cattle for improvement of sheep country, the greater will be the quantity and quality of beef produced. Saturation point in this direction appears to be a long way off.

(7) Increase in mechanization to reduce farm costs is being pushed by the Agriculture Department.

(8) The new Government has promised that there will be greater improvement in areas of marginal land, and has said that they will give consideration to reduction of taxation of overtime of the worker.

\section{Agricultural statistics for New Zealand}

Land in New Zealand can be divided into several categories. The total is $66,390,677$ acres, of which $23,290,853$ are quite unusable. In $1945^{-6}, 17,955,014$ acres were sown pasture, 2,254,880 in crop, $13,968,330$ in tussock and native grass, 2,708,429 native forest, 4,717,109 in fern and scrub, and $1,709,448$ were barren. Flax grew on 33,864 acres of swamp, so that the total occupied area was $43,099,824$ acres.

Table 2 shows the numbers as far as they can be obtained of livestock from 1937, until 1949. Actual figures for beef cattle are not available for earlier years. Figures for poultry are only obtained at intervals. The effect of the war years on supplies of superphosphate is clearly shown, as is the reduction of the pig population.

\section{Dependence of the Lnited Kingdom on certain imports from New Zealand}

'Table 3 shows how much the British consumer depends on New Zealand for certain high-grade commodities. The high cost of meat to the consumer is perhaps the biggest deterrent to the demand for ever increasing supplies. With improvement in grassing of marginal land, New \%ealand can go forward steadily, but she would not like to risk oversupplying the market. The table refers to 1948 , as a representative postwar year, and shows the total quantities of certain produce supplied to the United Kingdom from New Zealand, and the total imports into the United Kingdom from all sources.

'Table 3. Imports from New Zealand compared with total imports into the United Kingdom of lamb, mutton, beef, butter and cheese for 1948

\begin{tabular}{|c|c|c|c|}
\hline \multirow[b]{2}{*}{ Commodity } & \multirow[b]{2}{*}{$\begin{array}{l}\text { Total imports } \\
\text { (cwt.) }\end{array}$} & \multicolumn{2}{|c|}{ Imports from New Zealand } \\
\hline & & cw.t. & $\begin{array}{l}\text { Percentage } \\
\text { of total }\end{array}$ \\
\hline Lamb & $5,88_{3}, 22 \mathrm{I}$ & $3,8 \mathbf{2 9}, 786$ & $6_{5}$ \\
\hline Mutton & $1,795,582$ & $1,389,901$ & 77 \\
\hline Becf: boneless & $1,504,524$ & $705,189\}$ & \\
\hline frozen & $5,944,726$ & $592,732\}$ & 17 \\
\hline Butter & $5,+52,829$ & $2,717,701$ & 50 \\
\hline Cheese & $3,144,937$ & $1,661,112$ & 53 \\
\hline
\end{tabular}




\section{Conclusion}

The future of production in New Zealand is bright. Food production will increase steadily, and, provided seasons remain temperate, shipping facilities and standards improve, and refrigeration store space is available in Britain, the targets aimed at in New Zealand will be possible of attainment.

Much depends, too, on the improvement of marginal land and the continuous supply of superphosphate. The New Zealand farmer is a sane and well-informed member of the community, willing to pull his weight whenever difficult situations occur. He is backed by useful agricultural colleges and a live Agriculture Department, and the sale of produce is organized by representative bodies, the Meat Board and Dairy Commission. This has led to a stable primary industry.

\section{REFERE.NCES}

Board of Trade (1949). Annual Statement, 1947, Compared with the Years 1943-1946, Trade of the United Kingdom, with British Countries and Foreign Countries. London: H.M. Stationery Office.

Customs and Excise (1949). Accounts Relating to Trade and Navigation of the United Kingdom. London: H.M. Stationery Office.

\section{South Africa's Contribution to the British Diet}

By A. P. van DER Post (Senior Trade Commissioner for the Union of South Africa in the United Kingdom), South Africa House, Trafalgar Square, London, W.C. 2

The Union of South Africa can make only a limited contribution to the food requirements of the United Kingdom and that to a large extent only of luxury or semi-luxury articles of food. To appreciate the reason for this it is well briefly to examine the geophysical background of South African farming.

\section{Physical features of South Africa}

General climatic conditions. The Union, including South West Africa, together with the three Protectorates of Basutoland, Bechuanaland and Swaziland, occupies an area of $1,100,000$ square miles. This vast expanse can be divided into two main geographical areas, a coastal belt and an interior plateau, or rather series of plateaux, separated by an escarpment over 2000 miles long which begins in the west as a low ridge in South West Africa, gradually increases in stature towards the south and ends in the majestic Quathlamba Mountains or Drakensberge, in the north-north-east, in Basutoland and beyond along the border of Portuguese East Africa. In expanse the interior plateaux by far exceed the long but narrow coastal belt. Climatically the coastal belt can be subdivided into three main regions, a hot desert region in South West Africa and northern Cape Province, a 'Mediterranean' region in the so-called western Cape Province and south-western districts round Cape Town and a warm temperate region from roughly the border districts above East London, through the native territories of the Transkei and East Griqualand, Natal and Zululand to the Mozambique border. 